\title{
Effect of the Mobbing Perceptions of Physical Education and Sports Teachers on the Organizational Commitment Levels
}

\author{
Mustafa Vural*, Alper Tunga Peker \\ Department of Physical education and Sports, Ağrı İbrahim Çeçen University, Ağrı, Turkey
}

Copyright $\mathrm{C} 2018$ by authors, all rights reserved. Authors agree that this article remains permanently open access under the terms of the Creative Commons Attribution License 4.0 International License

\begin{abstract}
This research is conducted for the purpose of determining the effect of mobbing perceptions of physical education and sports teachers on the organizational commitments within the province Ağrı and its counties. In the research, a method for descriptive survey and relational survey intended to find out the present state, was used. The group of the research was consisted of total 248 physical education and sports teachers working in the different schools located at the province Ağrı and its counties in 2017-2018 education period. Organizational commitment scale of 18 items developed by Meyer and Allen (1991) and adapted into Turkish by Baysal and Paksoy (1999), "Negative Acts Questionnaire" Scale (NAQ) developed by Einarsen and Raknes (1997) and adapted into Turkish by Cemaloğlu (2007) and personal information form developed by the researcher were used for the research data. It was utilized from the Spearman Correlation (r) coefficient technique for finding out the correlation between the negative acts questionnaire scale (mobbing) and organizational commitment dimensions of teachers who participated into the research. The effect between the dependent and independent variables of the research was tested by the regression analysis. At the end of the research, it was found that there is a high-level of positive relation between the general organizational commitments and organizational commitment sub-dimensions of the physical education and sports teachers. It was concluded that the mobbing perceptions affected the organizational commitment levels significantly. The negative acts affect the organization commitment negatively at low level and changes occurred in the commitment is explained at about $6 \%$ rate. It was seen that the negative acts had a negative effect on the organizational commitment and it was found that mobbing practice affected the teachers' commitment to their schools negatively.
\end{abstract}

Keywords Physical Education and Sports, Mobbing, Organizational Commitment, Psychological Violence, Negative Act

\section{Introduction}

Many states and institutions in our age, in all areas of education level who can think on their own bass, process knowledge, individuals can make their own decisions emphasize the importance of training. In physical education, enabling people to socialize and cognitive is a set of activities that provide the sensory development. The physical education teacher; university of physical education teacher graduated from the section of teachers of primary and secondary schools physical education and sports training curriculum implements that could form the general cultural knowledge of general skills and teaching knowledge professions education are that person [1]. Physical education teachers are faced with many challenges when working in business life. Some of them are mobbing and organizational commitment. Physical education teachers in different ways in their school or institution is known that exposure to violence. Thus mobbing and discussed organizational affiliation subject.

An individual needs to work for maintaining his/her struggle for the life. It is seen that some problems have started to arise as a result of playing an active role in the business life. One of which is psychological pressure and violence that is mobbing. While the mobbing that is one of the problems which the individual encounter in the business life is known as a psychological pressure applied by superiors on the subordinates, it is not limited only with mobbing.

Latin "mobile vulgus" comes from the word "mobbing" word, unstable, overcrowded, carries meanings such as community oriented violence. In English "mob" action, to gather in one place, to attack is used to mean and disturbing. Concept of Mobbing, the first Austrian scientists in the 1960s, among them the man or animals by Konrad 
Lorenz lot of harassment to describe the behavior of non-practicing against a foreigner was used to. In the following years, the Swedish scientist Dr. Peter Paul Heinmann by addressing bullying and harassment incidents seen among students in school life, mobbing in 1972 in Sweden: Group Violence among published by the Children's book and children between observed bullying and despair of the victims because of mobbing cannot be retrieved front of acts of violence and fear has emphasized able to turn to behind the suicide [2].

The mobbing is the continuous acts which are hostile people perform systematically and also leave the employee alone and vulnerable with non-ethic behaviors. Such a condition that is too frequent and long-lasting leads the employee to suffer from psychological disorders and social pain [3].

Mobbing In fact, an individual's work life is systematically undergo psychological harassment and behavior of the source is not an event, focused on one person. The most obvious characteristics of mobbing;

- Making conscious,

- Systematically repeated,

- For a long time (at least six months) it continues to be,

- It aims to remove employees from work [4].

It was found in the research conducted that it is encountered with anxiety, depression, irritation, stress, anger, confusion and stress disorder, reduction in life satisfaction, unhappiness and many other psychological disorders in the persons being exposed to the mobbing [5]. Many factors are considered for experiencing all such negative situations occurred as a result of the mobbing in the organizations; these are colleagues in the working environment, workplace environment, working conditions, uncertainty of distribution of tasks, incapability of the executive, asocial individual and moral corruption in the organization [6]. Such negative situations in some studies are grouped as organizational reasons, social group-related reasons, personal reasons and reasons originating from tyrants [7].

Since such a situation, which becomes ever-increasing and frightening caused the individual who is pressurized to suffer from stress, disease and social problems, it decreases the productivity. This process leads workers to turn onto taking health reports, encounter accidents and live a life that is full of depressions [8]. The individual who experience various problems as a result of mobbing will decrease the productivity in the organization, move away from the organization by taking reports or break his/her all connections with the organization. In this context, problems of organization commitment will arise.

Organization commitment concept is an important phenomenon for the working individuals to adopt the inter-organization objectives, maintain the desire of staying in the organization, participate into organization's management and activities and demonstrate creative and innovative manner within the organization [9]. The organizational commitment expresses the strength of the tie which worker feels for the organization he/she works. For this reason, enabling the workers to be satisfied from the organization they work is seen as important as producing goods and/or services in terms of the organization [10]. Human has been always the leading among the necessary factors of the organization for a constant production. The existence of human is needed for an organization to exist and to be benefited from the existing technologies. Providing the continuity of people or workers, in general terms, to their organizations and works gains importance for continuing the activities in line with the objectives [11]. In the event that workers and executives whose organizational commitment is strong believe the values imposed by the organization, they contribute into the building up the organization's cultures. If the commitment of workers are truly for the organization and sincere, they are enabled to show a high performance in achieving the objectives of the organization [12]. Starting from this point of view, it was aimed in this study to search the organizational and work commitments of physical education and sports teachers once the problems and pressures they encountered in the schools are taken into account.

\section{Method}

\section{Research Model}

In the research, a method for descriptive survey and relational survey intended to find out the present state, was used. The descriptive survey models are the research approach, which aims to describe a past or still existing situation as is. The case, individual or object that is the subject of the research is tried to be described within its own conditions and as is. No effort for changing and affecting them in any way is made. The relational survey models are the research models intended to determine covariance existence and/or degree among two or more variables [13].

\section{Population and Sampling}

The population of the research was established as a result of interviews made with the Provincial Directorate of Ağrı National Education and it was found out that total 318 physical education teachers served in the province Ağrl and its counties in 2017-2018 education year. As it is, the population of the research was constituted by 318 physical education and sports teachers. It was reached to the province centre and all counties that is it was studied on the overall population, however, the sampling group was consisted of total 248 physical education and sports teachers due to teachers who were absent, on leave and did 
not want to participate into the questionnaire study voluntarily. The number of teacher of the sampling group who replied the questionnaire is given in the following Table 1 by the province and counties.

Table 1. The number of teacher who replied the questionnaire by the province Ağrı and cou、nties

\begin{tabular}{ccc}
\hline City Center and Counties & N & Percent\% \\
\hline Ağrı Merkez & 97 & 39 \\
Doğubayazıt & 48 & 19 \\
Diyadin & 16 & 7 \\
Patnos & 43 & 17 \\
Eleşkirt & 15 & 6 \\
Tutak & 12 & 5 \\
Taşlıçay & 8 & 3 \\
Hamur & 9 & 4 \\
Total & 248 & 100,0 \\
\hline
\end{tabular}

\section{Data Collection Tools}

Organizational commitment scale of 18 items developed by Meyer and Allen (1991) [14] and adapted into Turkish by Baysal and Paksoy (1999 [15], "Negative Acts Questionnaire" Scale (NAQ) developed by Einarsen and Raknes (1997) [16] and adapted into Turkish by Cemaloğlu (2007) [17] and personal information form developed by the researcher were used for measuring the organizational commitment, in the research.

\section{Data Analysis}

It was utilized from the Spearman Correlation (r) coefficient technique for finding out the correlation between the negative acts questionnaire scale (mobbing) and organizational commitment dimensions of teachers who participated into the research. The effect between the dependent and independent variables of the research was tested by the regression analysis. While assessing the correlation relationships between the scales, the result ranging between 1.00-0.70 was accepted as high-level relationship; 0.70 .30 as moderate-level relationship; $0.30-0.00$ as low-level relationship [18]. The results obtained for the analyses in the research were interpreted at the significance level of 0.01 . SPSS 23.0 package program was used for the data obtained in the research.

\section{Findings}

When Table 1 was considered, the relationship between negative acts scale and organizational commitment sub-dimensions of participants was examined. At the end of this examination; a high-level positive relationship was found out between general organizational commitment and all organizational commitment's sub-dimensions. It was determined that there is a moderate-level positive relationship among emotional commitment and continuance commitment and normative commitment of organizational commitment sub-dimensions and a again moderate-level positive relationship between continuance commitment and normative commitment.

It was found that there is a low-level negative relationship among negative acts scale (mobbing) and general organizational commitment and organizational commitment sub-dimensions.

Table 2. Correlation Matrix, Average and Standard Deviation Values of Variables

\begin{tabular}{|c|c|c|c|c|c|}
\hline & $\begin{array}{c}\text { General } \\
\text { Organizational } \\
\text { Commitment }\end{array}$ & $\begin{array}{l}\text { Emotional } \\
\text { Commitment }\end{array}$ & $\begin{array}{l}\text { Continuance } \\
\text { Commitment }\end{array}$ & $\begin{array}{l}\text { Normative } \\
\text { Commitment }\end{array}$ & $\begin{array}{c}\text { Negative Act Scale } \\
\text { (Mobbing) }\end{array}$ \\
\hline $\begin{array}{c}\text { General Organizational } \\
\text { Commitment }\end{array}$ & 1 & & & & \\
\hline Emotional Commitment &, $785^{* *}$ & 1 & & & \\
\hline Continuance Commitment &, $736^{* *}$ &, $301^{* *}$ & 1 & & \\
\hline Normative Commitment &, $830^{* *}$ &, $508^{* *}$ &, $514^{* *}$ & 1 & \\
\hline $\begin{array}{l}\text { Negative Acts Scale } \\
\text { (Mobbing) }\end{array}$ &,$- 278^{* *}$ &,$- 267^{* *}$ &,$- 135^{* *}$ &,$- 237^{* *}$ & 1 \\
\hline $\mathbf{X}$ & 3,48 & 3,60 & 3,46 & 3,37 & 1,80 \\
\hline SS & ,62 &, 87 & ,75 & ,72 & ,67 \\
\hline $\mathbf{N}$ & 248 & 248 & 248 & 248 & 248 \\
\hline
\end{tabular}

When Table 3 was examined, it is possible to state that the regression model established as a result of the value found as $p=, 000$ at the significance level $p<001$ for the regression model, is significant. $R^{2}$ value expresses that what percentage of the dependent variable is explained by the independent variables. It was found according to the significant value $(p=000<0.001)$ that there is a negative relationship $(\beta=-.239)$ between the negative acts (mobbing) and organizational commitment. Accordingly, we can say that negative acts (mobbing) affect the organizational commitment in the negative way. 
Table 3. Results of Regression Analysis conducted for Determining the Effect between Negative Acts Scale (Mobbing) and Organizational Commitment $(\mathrm{n}=248)$

\begin{tabular}{ccccccc}
\hline \multirow{2}{*}{$\begin{array}{c}\text { Independent } \\
\text { Variable }\end{array}$} & \multicolumn{5}{c}{$\begin{array}{c}\text { Dependent Variable: Organizational } \\
\text { Commitment }\end{array}$} \\
\cline { 2 - 7 } & $\mathbf{R}$ & $\mathbf{R}^{\mathbf{2}}$ & $\mathbf{F}$ & $\boldsymbol{\beta}$ & $\mathbf{t}$ & $\mathbf{p}$ \\
\hline $\begin{array}{c}\text { Negative } \\
\begin{array}{c}\text { Acts Scale } \\
\text { (Mobbing) }\end{array}\end{array}$ &, 239 &, 057 & 14,843 &,- 239 & $-3,853$ &, 000 \\
\hline $\mathrm{P}<001$ & & & & & & \\
\hline
\end{tabular}

\section{Discussion, Conclusion and Suggestions}

In the study conducted for the purpose of determining that to what extent organizational commitments of the physical education and sports teachers participated into the research change after the negative acts (mobbing) that is the relationship and effect between the mobbing perceptions and organizational commitment, the following results were obtained:

When these results obtained from the research findings were examined, a high-level positive relationship was found out between organizational commitment scale and sub-dimensions of physical education and sports teachers in Table 2. While a moderate-level positive relationship among emotional commitment and continuance commitment and normative commitment of organizational commitment sub-dimensions, a moderate-level positive relationship between continuance commitment and normative commitment. From these results, it is possible to say that once the emotional commitment properties of teachers (being close to the organization, identification of organization's objectives and being more motivated and willing in terms of contributing into the organization) increase, their continuance commitment (being committed to the organization or establishment, feeling himself/herself important within the organization, thinking that leaving is not correct since the employer or executive endeavored in the organization) and normative commitment properties (staying in the organization, devoting himself/herself to the organization, being faithful, making the working as a duty for himself/herself) will increase. When another result is examined, we can say that normative commitment properties of any teacher whose continuance commitment properties increased will also increase and on the contrary, while any one of them decreases, reduction will be seen in the other.

It was found that there is a low-level negative relationship between mobbing perceptions and organizational commitment scale sub-dimensions of the teachers who participated into the research. Accordingly, it was concluded that once there were negative acts (hostile, non-ethic acts and behaviors leaving the employee vulnerable and alone and showing continuous) and they continued, organizational commitments of the teachers also decreased. That is, we can say that existence of a negative relationship between mobbing and organizational commitment is the indicator of this.

Is more conflict in an organization's underlying conflicts mobbing can mean more spread. In organizations where it is a lot of organizational problems or a high level of uncertainty experienced emotional abuse can be very easy to apply until an employee. Such work environments can lead to various errors in the direction of individual work, in this case can be used to the detriment of individuals. The tension of the high level of the organization, said that support mobbing [17].

To be a lot of conflict in the organization will reduce the commitment to the organization. made this study revealed similar results with our study results.

When Table 3 of the research findings was examined, $\mathrm{R}$ value was found as 0,239 and corrected $R^{2}$ value was found as 0,057 at the end of regression analysis. Thus, according to the regression model, it was determined that independent variables explained about $6 \%$ of the changes occurred in the organizational commitment that is the dependent variable of the research. $\mathrm{F}$ value of the regression was found as 14,843 at a significance level of $1 \%$. When significance levels of regression coefficients were examined in Table 2, it was seen that negative acts, that is mobbing, which is the dependent variable affected the organizational commitment that is the dependent variable of the research significantly.

The negative acts, that is mobbing, have a negative effect on the organizational commitment in compliance with the research model. Mobbing $\beta$ coefficient was found as,- 239 . Accordingly, we can say that mobbing affects the organizational commitment in the negative way.

When the related literature was examined, it was seen that there are studies in which the relationship between mobbing and organizational commitment is searched. Of these studies, Hiçkorkmaz (2016) presented in his study named "Effect of Mobbing Perception on Organizational Commitment Level (Izmit Province Public Employees Sample)" conducted on public employees in Izmit province that mobbing perceptions affected the organizational commitments significantly and concluded at the end of the research that there was a negative relationship between mobbing and organizational commitment [19]. In another study, Belli (2014) found in his study named "Research of Mobbing Levels of the Personnel working in Youth Services and Sports Provincial Directorates and Evaluation in terms of Organizational Commitment" that there was a significant relationship between mobbing perceptions and organization commitment levels of the personnel who constituted the sampling group and explained that this relationship was a negative strong one [20]. Atalay (2010) who found a significant relationship between the organizational commitment and mobbing explained this relationship as negative (21). IN the study conducted by Ozler et al., (2008), they examined the relationship 
between mobbing and organizational commitment and found that there was a negative significant relationship [22].

The studies conducted found that mobbing practice caused a decrease in job satisfaction and organizational commitments of employees and also, lead them to consider to leave of employment [23].

When the literature was examined in general terms, it is seen that there was a negative relationship between the organization commitment and mobbing. That is, it was concluded that organizational commitments of employees who were exposed to mobbing or negative acts also decrease. Results obtained in the literature research are in parallel with the research results and they are compatible with the research findings and results.

Suggestions to be given on the basis of research findings are as follows:

- Trainings related with mobbing may be given in institutions and organizations and organizational commitments of employees may be increased.

- Solidarity environments may be created with confidence, cooperation and sharing between the employees and employers in the organizations.

- Mobbing reasons are determined and training and psychological support may be given to employees.

- More importance may be given to the ideas of employees in the organizations and sense of belonging may be increased.

- Studies may be performed with different working groups.

- Mobbing and commitment levels of teachers may be searched over demographical variables and it may be contributed into the field.

\section{REFERENCES}

[1] Eroğlu C. Beden Eğitimi Öğretmen Adaylarının ÖzYeterlilikleri Ve Öğretmenlik Mesleğine Yönelik Tutumları, Yüksek Lisans Tezi, Aksaray Üniversitesi Sosyal Bilimler Enstitüsü, Aksaray 2013; 1-84.

[2] Eser, Oktay; Mobbing Kavramının Türkçe Serüveni. http://turkoloji.cu.edu.tr/YENI\%20TURK\%20DILI/oktay_ eser_mobbing_kavrami.pdf(Erişim:25.10.2018). (1)

[3] Leymann, H. (1990), "Mobbing and Psychological Terror At Workplaces". Violence and Victims, 5(2).

[4] https://mobbingturkey.wordpress.com/ (erişim: 25.10.2018 ).

[5] Cicerali, L.K. (2011), "Mobbinge Maruz Kalanların Kişilik Profillerine Bağlı Psikolojik Sağlıkta Bozulma Göstergeleri'" Doktora Tezi, Istanbul Üniversitesi.

[6] Einarsen S. (1999). The nature and causes of bullying at work, International Journal of Manpower, 20(1/2):16-27
[7] Zapf, D. (2005), Organisational, Work Group Related And Personal Causes of Mobbing/ Bullying at Work, International Journal of Manpower.

[8] Davenport, N., Schwartz, R. D. ve Elliott, G. P. (2003). Mobbing, İşyerinde Duygusal Taciz. (Çev.: Osman Cem Önertoy). Ankara: Sistem Yayıncılık.

[9] Eren V, Durna U. (2005). Üç bağllık unsuru ekseninde örgütsel bağl1lık, Doğuş Üniversitesi Dergisi,6: 210-219.

[10] Çöl, G . (2004)."Örgütsel Bağlılık Kavramı ve Benzer Kavramlarla İlişkisi". ISGUC The Journal of Industrial Relations and Human Resources 6:2.

[11] Güçlü H. (2006). Turizm sektöründe durumsal faktörlerin örgütsel bağlllık üzerindeki etkisi, Anadolu Üniversitesi Yayınları, , no.1681, Eskişehir.

[12] Jones, G. R., \& George, J. M. (2003). Contemporary management (3rd ed.). New York: McGraw-Hill/Irwin.

[13] Karasar N. (2004). Bilimsel Araştırma Yöntemi. Ankara, Nobel Yayınc1lik.

[14] Meyer, J.P. - Ailen, N.J.(1991) , A theree compment conceptualization of organizational commitment. Humen Resource Management Rewiew, 1,61 - 98.

[15] Baysal, A.C. ve Paksoy M. (1999), "Mesleğe ve Örgüte Bağlllı̆ı̆in Çok Yönlü İncelenmesinde Meyer-Allen Modeli”, İstanbul Üniversitesi İșletme Fakültesi Dergisi, 28 (1), ss. 7-15.

[16] Einarsen, S. ve Raknes, B.I. (1997). Harassment in the workplace and the victimization of men. Violence and Victims, 12,247-263.

[17] Cemaloğlu，N. (2007). "Okul Yöneticilerinin Liderlik Stilleri ile Yıldırma Arasındaki İlişki”. H. Ü. Eğitim Fakültesi Dergisi, (33), 77-87

[18] Büyüköztürk Ș. (2007). Sosyal Bilimler İçin Veri Analizi El Kitabı. 7. Bask1, Ankara, Pegem Yayıncılık.

[19] Hiçkorkmaz, S. (2016).Mobbing Algısının Örgütsel Bağlllık Düzeyi Üzerindeki Etkisi (İzmit İlçesi Kamu Çalışanları Örneği). Yüksek lisans tezi, Nişantaşı üniversitesi, sosyal bilimler enstitüsü. İstanbul.

[20] Belli, E. (2014). Gençlik Hizmetleri ve Spor İl Müdürlüklerinde Çalışan Personelin Mobbing Düzeylerinin Araştırılması ve Örgütsel Bağl1lı Yönünden Değerlendirilmesi. Doktora Tezi, Atatürk Üniversitesi Sağlık Bilimleri Enstitüsü.

[21] Atalay İ. (2010) .Mobbing'in Örgütsel Bağlllık Üzerindeki Etkisi "Kamu Sektöründen Bir Örnek". Sosyal Bilimler Enstitüsü, İşletme Anabilim Dalı. Yüksek Lisans Tezi, Ankara: Atılım Üniversitesi,

[22] Özler EG, Atalay GC, Sahin DM. (2008). Mobbing'in örgütsel bağll1ık üzerine etkisini belirlemeye yönelik bir araştırma. Dumlupınar Üniversitesi Sosyal Bilimler Dergisi, 4: 22 .

[23] Vartia, M. (1996). "The Sources of Bullying-Psychological Work Environment and Organizational Climate", European Journal of Work and Organizational Psychology, 2: 203-214. 